\title{
Novel perspectives on the role of the human microbiota in regenerative medicine and surgery (Review)
}

\author{
TOMMASO PELLEGATTA $^{1 *}$, MARCO SALER $^{1^{*}}$, VIOLA BONFANTI $^{*}$, \\ GIOVANNI NICOLETTI $^{1,2}$ and ANGELA FAGA ${ }^{1,2^{*}}$ \\ ${ }^{1}$ Department of Clinical-Surgical, Diagnostic and Pediatric Sciences, Plastic Surgery Unit, \\ University of Pavia, Pavia, I-27100 Lombardy; ${ }^{2}$ Plastic and Reconstructive Surgery Unit, \\ Salvatore Maugeri Research and Care Institute, Pavia, I-27100 Lombardy, Italy
}

Received July 14, 2016; Accepted September 21, 2016

DOI: $10.3892 /$ br.2016.778

\begin{abstract}
Plastic surgery is transitioning from a fine craftsmanship to a regenerative science. In wound healing, the role of microorganisms is no longer considered to be just counteracting, but also promoting. Furthermore, host-microbe interactions are essential for numerous aspects of normal mammalian physiology, from metabolic activity to immune homeostasis. Each area of the human body hosts a unique microbial community, and the composition of microbiota is dependent on the host, age and the anatomical area, and it changes according to the characteristics of the microenvironment. Every squared centimeter of skin contains $\sim 1$ billion bacteria. The majority of microorganisms of the skin are commensal or temporary passing members. Skin flora mechanisms interacting or influencing the human physical skin barrier are not well defined. Resident skin bacteria provide the first line of defence against potentially dangerous pathogens and produce small molecules that influence their microbial neighbours. Furthermore, the microbiota activates and assists innate immunity and influences adaptive immunity. Various types of immune and non-immune cells contribute to wound healing. The proliferative phase of wound healing is inversely proportional to the extent of the post-traumatic inflammatory reaction. Topical bacterial lipopolysaccharide application markedly affects wound healing by accelerating the resolution of inflammation, increasing macrophage infiltration, enhancing collagen synthesis and altering the secretion of mediators involved in skin regeneration. Various studies have investigated the biological contents of thermal spring waters,
\end{abstract}

Correspondence to: Professor Angela Faga, Department of Clinical-Surgical, Diagnostic and Pediatric Sciences, Plastic Surgery Unit, University of Pavia, 74 Via Brambilla, Pavia, I-27100 Lombardy, Italy

E-mail: angela.faga@unipv.it

*Contributed equally

Key words: regenerative medicine and surgery, microbiota, spring water and their anti-inflammatory and immune protective roles. In addition, the regenerative properties of thermal spring waters were analysed in an experimental animal wound model. The areas treated with thermal water healed faster than the areas treated with conventional dressings, and exhibited a collagen and elastic fiber network comparable with the normal skin. Thus, the microbial environment may be considered as a potential tool in regenerative medicine and surgery.

\section{Contents}

1. Introduction

2. From reparative to regenerative surgery

3. Microbiota and the National Institutes of Health Human Microbiome Project

4. Skin microbiota

5. Human microbiota in health and diseases

6. The future of regenerative surgery

7. Conclusion

\section{Introduction}

Tissue regeneration is a fascinating subject, which has always attracted the attention of scientists. As yet the underlying mechanisms of prolonging the existence of complex organisms (by restoring the cells destroyed by trauma or damaged by diseases and aging) are not completely understood. Amongst the medical specialties, plastic surgery is predominantly concerned with investigating tissue repair, which represents the basis of a positive outcome of any surgery. In addition, advanced knowledge of anatomy and biology has resulted in increased understanding of plastic surgery. Thus, plastic surgery is currently transitioning from a fine craftsmanship to a molecular and regenerative type of medicine.

\section{From reparative to regenerative surgery}

The aims of plastic surgery are the repair of anatomical defects, and restoration of the functions and appearance of the body. These goals are traditionally achieved with the use of 
autologous tissues. In current, daily practice autologous tissue transplantation is the only realistic choice, as homologous tissue transplantation is burdened by the hazardous side effect of lifelong, severe immunosuppressive treatment.

In recent years the term 'Regenerative Medicine' has been introduced, defined as an emerging interdisciplinary field of research and clinical applications focused on the repair, replacement or regeneration of cells, tissues or organs (1). Regenerative medicine was established as the combination of various technological approaches, which includes, but is not limited to, the use of soluble molecules, gene therapy, stem cell transplantation, tissue engineering and the reprogramming of cell and tissue types (1-3).

Unlike the animals on the lowest branches of the phylogenetic tree, in humans true spontaneous regeneration only occurs in early fetal life, where the wound healing process produces normal tissue rather then a scar $(4,5)$. Although the primary contribution to fetal regeneration has been associated with the environment $(6,7)$, other studies are demonstrating that intrinsic factors are critical; therefore, fibroblasts are currently the main target of studies regarding skin regeneration $(5,8,9)$.

As a result of these novel concepts, plastic surgery is progressively overcoming limitations, and increasingly becoming integrated with other disciplines and sciences. The performance of plastic surgery is becoming more prevalent, particularly for elderly individuals who are affected by severe comorbidities and require extended surgical procedures. Therefore, regenerative plastic surgery is becoming more feasible for challenging patients (10). Regenerative medicine and surgery is characterized by three major fields; tissue engineering, biomaterials/biomolecules and stem cell therapy.

\section{Microbiota and the National Institutes of Health Human Microbiome Project}

Multiple factors are involved in the wound healing process and the significant role of microorganisms is well known. In the past, the influence of microorganisms was investigated only during pathologic events; however, the growing interest in microbiology and the availability of novel technologies allow greater analysis of their association with the host. Microorganisms are present in every type of environmental niche and interplay with all its components.

The term microbiota is used in the current study to define the microbial community hosted on the surface of the human body, which is composed of bacteria, viruses, fungi and archei, and the term microbiome for the whole genome of the community (11). Microbial cells living on the surface of the human body outnumber the totality of cells of our organism by a factor of ten, and the genes of those microbial cells outnumber the human genes by a factor of hundred (12). Host-microbe interactions are essential for various aspects of normal mammalian physiology, ranging from metabolic activity to immune homeostasis (13-19). Every area of the human body hosts a unique microbial community. The transmigration of microorganisms from one community to another, (due to, for example, environmental factors, genetic variations, life styles, hygiene habits and immunity) is associated with different pathologies. Furthermore, the microbial community is ruled by specific microbial communications, cell signalling, metabolic interactions and quorum sensing (20). Therefore the association between the human organism and the microbiota might be considered as a 'superorganism' (21).

From 2008, starting with the U.S.A. Human Microbiome Project (HMP), different studies were established to establish a database of the human microbiome in order to demonstrate any possible associations between the microbiota, and health and disease conditions (22-24). However, microbiota characterization is hampered by the difficulty to recreate the same conditions in vitro as in vivo (25). With the aid of current metagenomics techniques it is possible to screen the whole genes of an environmental sample and to create a genetic library of the proteins expressed by the community (26). Moving from conventional cultures to metagenomics, a prospective change is occurring, focusing on the activity and products of a whole community, rather than on a single community member (27).

\section{Skin microbiota}

Skin is the first defense line of the human body and houses different populations of microorganisms. The acquisition of its microbiota begins at birth (28), with the transfer of maternal microbiota, and differs between vaginal and caesarian delivery. The skin microbiota evolves over the years according to the changes of skin structure and functions (29) becoming similar to that of adults by the age of 12-18 months (30). In addition, individuals acquire their own microbiota through contact with other individuals, visiting different places, and eating food. Furthermore, microbiota composition changes according to ethnicity, geography and life style (12). Every squared centimeter of skin (including hair follicles and sebaceous glands) contains $\sim 1$ billion bacteria (31).

The majority of the microorganisms of the skin microbiota are commensal or just temporary passing members. The following four bacterial phyla are present on human skin: Actinobacteria, Proteobacteria, Firmicutes and Bacteroidetes. Staphylococcus, Propionibacterium and Corynebacterium (12) are the dominant genera, and are constants in interindividual distribution. Differences from host-to-host are due to the less represented bacteria. In addition, in normal human skin, there are viruses (human papillomavirus, human polyomavirus, circovirus and bacteriophages) and eucaryotes microbes (fungi and protists) (32).

The composition of microbiota is dependent on the host, their age and the anatomical area, and it changes according to the characteristics of the microenvironment, which is regulated by skin adnexa (12). Microbiota $\alpha$-diversity expresses the difference in community composition, comparing a specific area of the body to other areas of the same individual. Microbiota $\beta$-diversity expresses the difference in community composition comparing a specific area of the body between different individuals. Notably, antecubital fossae have the highest $\beta$-diversity, but the lowest $\alpha$-diversity (33). Considering the community composition in different individuals, it is possible to state that the microbiota of an individual is as unique as a fingerprint (31,33-38).

Metagenomic techniques demonstrate bacterial DNA deep in the dermis, although such a technology may not assess the viability of the associated microorganisms $(12,32)$. Furthermore, it is well established that microorganisms do not 
have to be alive to exert their influence on the host immune system (39-45). However, it is possible that certain microbes do survive below the epithelial barrier, but cannot be successfully cultured by current techniques. In addition, the microbiota resident on the skin surface may be translocated to a subepidermal level by phagocytic cells . Epidermal physical barriers or antimicrobial peptides (AMPs) may serve as key regulators in the maintenance of dermal microbiome homeostasis, and bacterial activity to counteract the host immune response may also contribute to dermal microbiota development (46). The skin is an active immune organ where keratinocytes can no longer be considered as the sole barrier against the external environment, although they must be considered as active components of the immunoregulatory network within the external environment, the resident cutaneous immune system and the microbiota (47). Skin flora mechanisms interacting or influencing the human physical skin barrier remain poorly defined (48). Resident skin bacteria provide the first line of defence against potentially dangerous pathogens, and produce small molecules that influence the growth and behaviour of their microbial neighbours. It is important to acknowledge that skin bacteria act in synergy and in opposition to the immune system (49).

The microbiota activates and assists innate immunity, as well as influences adaptive immunity, although these complex interactions are not completely understood (49-60). As skin microbiota is important in the development of a well functioning immune system and in the modulation of the inflammatory processes, it may be significant in the wound healing process and serve as a protective factor against cancer development.

\section{Human microbiota in health and diseases}

Current concepts regarding the interactions at a molecular level between a co-evolved microbiota and the host (13-19) suggest a complete re-examination of human physiology and immunology (61). The reciprocal, beneficial association between the host and the microbiota begins immediately after birth; various studies state that the microbiota of newborns differ markedly according to the delivery mode. In the case of vaginal delivery, it resembles the vaginal microbiota; however, if a caesarean delivery occurs, the microbiota resembles the skin microbiota. Recent studies demonstrated that birth by caesarean delivery is associated with an increased risk of developing metabolic and immune diseases (62). For this reason, the practice of vaginal seeding has recently been proposed; it consists of transferring the mother's birth canal microbiota onto the skin of the newborn using a vaginal swab. This practice may integrate the microbiota of infants and decrease their risk of developing metabolic and immune diseases later in life (63).

Currently, the gut microbiota are the most extensively investigated. A change in gut homeostasis is associated with the onset of various severe pathological conditions, including inflammatory bowel disease (IBD) (64), a chronic relapsing inflammatory condition comprised of two clinically and morphologically different entities: Ulcerative colitis and Crohn's disease. Although the etiology of IBD is unknown, the predominant hypothesis suggests that inflammation results from a sustained immune response towards altered or pathogenic microbiota within a genetically susceptible host (65).
A successful example of microbiota transfer as a therapeutic tool against dysbiosis (an imbalance between beneficial and potentially harmful bacteria) (66) has been accomplished through fecal transplantation in patients affected by recurrent enteric Clostridium difficile infections. The microbiota of healthy donor feces reconstitutes the compromised intestinal microbiota in a substantial and durable way (67). The role of dysbiosis has been advocated in a wide range of diseases, including IBD and asthma, diabetes mellitus type 1, obesity, cardiovascular diseases, insulin-resistance, dyslipidemia and psychiatric conditions $(13,68-83)$.

Recent studies indicate that the synergy between the skin microbiota and the local immune system controls the homeostasis of the complex epithelial barrier (84). The major innate mechanism of the antimicrobial defence of the skin consists of AMPs, such as defensins, cathelicidin LL-37 and dermcidin (85). These peptides are emerging as important tools in the control of skin pathogenic bacteria. Skin lesions caused by atopic dermatitis (AD) present lower levels of various AMPs than normal skin, contributing to an increased susceptibility to infections $(86,87)$. In addition, current studies have identified the presence of certain polymorphisms in Toll-like receptors (TLRs) or TLR signalling molecules in patients with AD. Furthermore, the skin microbiota influences the immune system, through a promoting effect on $\mathrm{T}$ cell response, controlling nuclear factor- $\kappa \mathrm{B}$ signaling and the production of cytokines, such as tumor necrosis factor (TNF)- $\alpha$ and interleukin-1 $\beta$ (88).

Germ-free mice without commensal skin microbes have been demonstrated to produce abnormal cytokine and cutaneous T-cell populations, as they were unable to mount an appropriate immune response against the intradermal Leishmania major infection; immunity could be rescued by allowing Staphylococcus epidermidis colonization on the mouse skin (89). The consensus on the role of microbiota in skin diseases led to an international project, Microbes in Allergy and Autoimmunity Related to the Skin, the aim of which is to identify the microorganisms triggering and countering allergy and autoimmune diseases (90).

\section{The future of regenerative surgery}

Many types of immune and non-immune cells, including macrophages, neutrophils, platelets, fibroblasts, vascular endothelial cells and keratinocytes contribute to wound healing. The inflammatory response begins immediately upon injury and leads to the secretion of a variety of growth factors and cytokines, which regulate the cellular and tissue movements that are required for repair $(91,92)$. It has been demonstrated that the proliferative phase of wound healing is inversely proportional to the quantity of inflammatory post-traumatic reaction (93). Topical bacterial lipopolysaccharide treatment markedly affects the wound healing process by accelerating the resolution of inflammation, increasing macrophage infiltration, enhancing collagen synthesis and altering the secretion of numerous mediators involved in the skin regeneration process (94); all of these effects demonstrate the role of microorganisms in the modulation of the inflammatory response.

Inoculation withPseudomonasaeruginosawasdemonstrated to accelerate re-epithelialization and neovascularization 
in wound tissues. Neutrophil infiltration, which actively contributes to the wound healing processes, was also promoted by this bacterium through the production of TNF- $\alpha$ (95). It has long been known that the healing of skin irritations and skin lesions can be boosted by topical applications of spring waters where a rich presence of non-pathogenic microflora is established (96-100). In recent years, research programs have been developed to investigate the biological contents of spring waters, and their anti-inflammatory and immune protective roles. The incubation of human keratinocytes with I-modulia, a biological extract from cultures of Aquaphilus dolomiae, showed an upregulation of the innate immune response (101). Aquaphilus dolomiae is a non-spore forming bacterium belonging to the Neisseriaceae family, which is isolated from Avène thermal Water (France), historically used in the management of chronic inflammatory skin diseases. Similarly, the lysate of Vitreoscilla filiformis (VF) has been shown to enhance skin defence mechanisms (102) and to decrease UV-induced sunburn cells in human skin, possibly by the activation of cutaneous regulatory T cells (103). VF is a filamentous Gram-negative aerobic bacterium belonging to the Neisseriaceae family found in LaRoche-Posay thermal water, historically applied to manage chronic inflammatory skin diseases (103-105).

The regenerative properties of an Italian spring water (Comano, TN) were also assessed in an experimental animal wound model. The areas treated with this water healed faster than the areas treated with conventional medical dressings, and demonstrated a network of collagen and elastic fibers that was comparable with the normal skin (99). This spring water was then analyzed at the microbial level and a total of nine non-pathogenic different strains were isolated, which are likely to produce molecular mediators with a role in the wound healing process (100). Thus, the role of microbiota in health maintenance appears to be of paramount importance and, as a consequence, indicates towards a hypothesis of exerting a positive effect in the skin healing processes. At the microbial level, the distinction between human health and disease is important only as far as it affects the microbial condition. Ignoring the association between host and microbiota in therapeutical planning is a shortsighted conduct, as demonstrated by the spread of antibiotic-resistant microorganisms (106-111).

\section{Conclusion}

The mechanisms upon which the microbial community structure and the association between host and symbiont are based must become incorporated into the current definition of human health. Medical intervention must aim to minimize or avoid damage to health-associated homeostasis between humans and their microbiota; therefore the therapeutic strategies to maintain healthy skin may require the inhibition of the growth of pathogenic bacteria, as well as the promotion of a balanced microbiota. Thus, the role of microbiota is resulting in novel and fascinating scenarios in regenerative medicine and surgery with unexpected progress.

\section{References}

1. Daar AS and Greenwood HL: A proposed definition of regenerative medicine. J Tissue Eng Regen Med 1: 179-184, 2007.
2. Daar AS: The future of replacement and restorative therapies: From organ transplantation to regenerative medicine. Transplant Proc 45: 3450-3452, 2013.

3. Blum HE: Advances in individualized and regenerative medicine. Adv Med Sci 59: 7-12, 2014.

4. Lo DD, Zimmermann AS, Nauta A, Longaker MT and Lorenz HP: Scarless fetal skin wound healing update. Birth Defects Res C Embryo Today 96: 237-247, 2012.

5. Lorenz HP, Longaker MT, Perkocha LA, Jennings RW, Harrison MR and Adzick NS: Scarless wound repair: A human fetal skin model. Development 114: 253-259, 1992.

6. Wulff BC, Parent AE, Meleski MA, DiPietro LA, Schrementi ME and Wilgus TA: Mast cells contribute to scar formation during fetal wound healing. J Invest Dermatol 132: 458-465, 2012.

7. Longaker MT, Chiu ES, Harrison MR, Crombleholme TM, Langer JC, Duncan BW, Adzick NS, Verrier ED and Stern R: Studies in fetal wound healing. IV. Hyaluronic acid-stimulating activity distinguishes fetal wound fluid from adult wound fluid. Ann Surg 210: 667-672, 1989.

8. Longaker MT, Whitby DJ, Ferguson MW, Lorenz HP, Harrison MR and Adzick NS: Adult skin wounds in the fetal environment heal with scar formation. Ann Surg 219: 65-72, 1994.

9. Walmsley GG, Maan ZN, Wong VW, Duscher D, Hu MS, Zielins ER, Wearda T, Muhonen E, McArdle A, Tevlin R, et al: Scarless wound healing: Chasing the holy grail. Plast Reconstr Surg 135: 907-917, 2015.

10. Cervelli V and Gentile P: La rigenerazione dei tessuti tra storia e mitologia. In: Chirurgia Plastica Rigenerativa. Universo SE (ed). Roma, pp1-3, 2015.

11. Casadevall A and Pirofski LA: What is a host? Incorporating the microbiota into the damage-response framework. Infect Immun 83: 2-7, 2015.

12. Grice EA: The skin microbiome: Potential for novel diagnostic and therapeutic approaches to cutaneous disease. Semin Cutan Med Surg 33: 98-103, 2014.

13. Bäckhed F, Ding H, Wang T, Hooper LV, Koh GY, Nagy A, Semenkovich CF and Gordon JI: The gut microbiota as an environmental factor that regulates fat storage. Proc Natl Acad Sci USA 101: 15718-15723, 2004.

14. Cash HL, Whitham CV, Behrendt CL and Hooper LV: Symbiotic bacteria direct expression of an intestinal bactericidal lectin. Science 313: 1126-1130, 2006.

15. Guarner F, Bourdet-Sicard R, Brandtzaeg P, Gill HS, McGuirk P, van Eden W, Versalovic J, Weinstock JV and Rook GA: Mechanisms of disease: The hygiene hypothesis revisited. Nat Clin Pract Gastroenterol Hepatol 3: 275-284, 2006.

16. Kelly D, Campbell JI, King TP, Grant G, Jansson EA, Coutts AG, Pettersson S and Conway S: Commensal anaerobic gut bacteria attenuate inflammation by regulating nuclear-cytoplasmic shuttling of PPAR- $\gamma$ and RelA. Nat Immunol 5: 104-112, 2004.

17. Martin FP, Dumas ME, Wang Y, Legido-Quigley C, Yap IK, Tang H, Zirah S, Murphy GM, Cloarec O, Lindon JC, et al: A top-down systems biology view of microbiome-mammalian metabolic interactions in a mouse model. Mol Syst Biol 3: 112, 2007.

18. Mazmanian SK, Liu CH, Tzianabos AO and Kasper DL: An immunomodulatory molecule of symbiotic bacteria directs maturation of the host immune system. Cell 122: 107-118, 2005.

19. Rakoff-Nahoum S, Paglino J, Eslami-Varzaneh F, Edberg S and Medzhitov R: Recognition of commensal microflora by toll-like receptors is required for intestinal homeostasis. Cell 118: 229-241, 2004.

20. Wright GD: Antibiotic resistance in the environment: A link to the clinic? Curr Opin Microbiol 13: 589-594, 2010.

21. Foxman B, Goldberg D, Murdock C, Xi C and Gilsdorf JR: Conceptualizing human microbiota: From multicelled organ to ecological community. Interdiscip Perspect Infect Dis 2008: 613979, 2008.

22. Turnbaugh PJ, Ley RE, Hamady M, Fraser-Liggett CM, Knight R and Gordon JI: The human microbiome project. Nature 449: 804-810, 2007.

23. Peterson J, Garges S, Giovanni M, McInnes P, Wang L, Schloss JA, Bonazzi V, McEwen JE, Wetterstrand KA, Deal C, et al; NIH HMP Working Group: The NIH Human Microbiome Project. Genome Res 19: 2317-2323, 2009.

24. Ehrlich SD: The MetaHIT Consortium: MetaHIT: The European Union project on metagenomics of the human intestinal tract. In: Metagenomics of the human body. Springer (ed), New York, pp 307-316, 2011. 
25. Huss J: Methodology and ontology in microbiome research. Biol Theory 9: 392-400, 2014.

26. National Research Council (US) Committee on Metagenomics: The New Science of Metagenomics: Revealing the Secrets of Our Microbial Planet. The National Academies Press (ed), Washington (DC), 2007.

27. Schloss PD: Microbiology: An integrated view of the skin microbiome. Nature 514: 44-45, 2014

28. Dominguez-Bello MG, Costello EK, Contreras M, Magris M, Hidalgo G, Fierer N and Knight R: Delivery mode shapes the acquisition and structure of the initial microbiota across multiple body habitats in newborns. Proc Natl Acad Sci USA 107: 11971-11975, 2010.

29. Baviera G, Leoni MC, Capra L, Cipriani F, Longo G, Maiello N, Ricci G and Galli E: Microbiota in healthy skin and in atopic eczema. BioMed Res Int 2014: 436921, 2014.

30. Capone KA, Dowd SE, Stamatas GN and Nikolovski J: Diversity of the human skin microbiome early in life. J Invest Dermatol 131: 2026-2032, 2011.

31. Grice EA, Kong HH, Renaud G, Young AC, Bouffard GG, Blakesley RW, Wolfsberg TG, Turner ML and Segre JA; NISC Comparative Sequencing Program: A diversity profile of the human skin microbiota. Genome Res 18: 1043-1050, 2008.

32. Findley $\mathrm{K}$ and Grice EA: The skin microbiome: A focus on pathogens and their association with skin disease. PLoS Pathog 10: e1004436, 2014.

33. Huttenhower C, Gevers D, Knight R, Abubucker S, Badger JH ChinwallaAT,CreasyHH,EarlAM,FitzGeraldMG,FultonRS,etal Human Microbiome Project Consortium: Structure, function and diversity of the healthy human microbiome. Nature 486: 207-214, 2012.

34. Costello EK, Lauber CL, Hamady M, Fierer N, Gordon JI, Knight R, Gordon JI and Knight R: Bacterial community variation in human body habitats across space and time. Science 326: 1694-1697, 2009.

35. Grice EA, Kong HH, Conlan S, Deming CB, Davis J, Young AC, Bouffard GG, Blakesley RW, Murray PR, Green ED, et al; NISC Comparative Sequencing Program: Topographical and temporal diversity of the human skin microbiome. Science 324: 1190-1192, 2009.

36. Eckburg PB, Bik EM, Bernstein CN, Purdom E, Dethlefsen L, Sargent M, Gill SR, Nelson KE and Relman DA: Diversity of the human intestinal microbial flora. Science 308: 1635-1638, 2005.

37. Vanhoutte T, Huys G, Brandt E and Swings J: Temporal stability analysis of the microbiota in human feces by denaturing gradient gel electrophoresis using universal and group-specific 16S rRNA gene primers. FEMS Microbiol Ecol 48: 437-446, 2004.

38. Ley RE, Peterson DA and Gordon JI: Ecological and evolutionary forces shaping microbial diversity in the human intestine. Cell 124: 837-848, 2006.

39. Yuki T, Yoshida H, Akazawa Y, Komiya A, Sugiyama Y and Inoue S: Activation of TLR2 enhances tight junction barrier in epidermal keratinocytes. J Immunol 187: 3230-3237, 2011.

40. Lai Y, Di Nardo A, Nakatsuji T, Leichtle A, Yang Y, Cogen AL, Wu ZR, Hooper LV, Schmidt RR, von Aulock S, et al: Commensal bacteria regulate Toll-like receptor 3-dependent inflammation after skin injury. Nat Med 15: 1377-1382, 2009.

41. Lai Y, Cogen AL, Radek KA, Park HJ, Macleod DT, Leichtle A, Ryan AF, Di Nardo A and Gallo RL: Activation of TLR2 by a small molecule produced by Staphylococcus epidermidis increases antimicrobial defense against bacterial skin infections. J Invest Dermatol 130: 2211-2221, 2010.

42. Wanke I, Steffen H, Christ C, Krismer B, Götz F, Peschel A, Schaller M and Schittek B: Skin commensals amplify the innate immune response to pathogens by activation of distinct signaling pathways. J Invest Dermatol 131: 382-390, 2011.

43. Round JL, Lee SM, Li J, Tran G, Jabri B, Chatila TA and Mazmanian SK: The Toll-like receptor 2 pathway establishes colonization by a commensal of the human microbiota. Science 332: 974-977, 2011

44. Atarashi K, Nishimura J, Shima T, Umesaki Y, Yamamoto M, Onoue M, Yagita H, Ishii N, Evans R, Honda K, et al: ATP drives lamina propria $\mathrm{T}(\mathrm{H}) 17$ cell differentiation. Nature 455 : 808-812, 2008.

45. Hall JA, Bouladoux N, Sun CM, Wohlfert EA, Blank RB, Zhu Q, Grigg ME, Berzofsky JA and Belkaid Y: Commensal DNA limits regulatory $\mathrm{T}$ cell conversion and is a natural adjuvant of intestinal immune responses. Immunity 29: 637-649, 2008.

46. Nakatsuji T, Chiang HI, Jiang SB, Nagarajan H, Zengler K and Gallo RL: The microbiome extends to subepidermal compartments of normal skin. Nat Commun 4: 1431, 2013.
47. Sanchez Rodriguez R, Pauli ML, Neuhaus IM, Yu SS, Arron ST, Harris HW, Yang SH, Anthony BA, Sverdrup FM, Krow-Lucal E, et al: Memory regulatory T cells reside in human skin. J Clin Invest 124: 1027-1036, 2014

48. Aberg KM, Man MQ, Gallo RL, Ganz T, Crumrine D, Brown BE, Choi EH, Kim DK, Schröder JM, Feingold KR, et al: Co-regulation and interdependence of the mammalian epidermal permeability and antimicrobial barriers. J Invest Dermatol 128 917-925, 2008

49. Gallo RL and Nakatsuji T: Microbial symbiosis with the innate immune defense system of the skin. J Invest Dermatol 131: 1974-1980, 2011

50. Gallo RL, Murakami M, Ohtake T and Zaiou M: Biology and clinical relevance of naturally occurring antimicrobial peptides. J Allergy Clin Immunol 110: 823-831, 2002.

51. Lai Y and Gallo RL: AMPed up immunity: How antimicrobial peptides have multiple roles in immune defense. Trends Immunol 30: 131-141, 2009.

52. Wiesner J and Vilcinskas A: Antimicrobial peptides: The ancient arm of the human immune system. Virulence 1: 440-464, 2010.

53. Nagy I, Pivarcsi A, Kis K, Koreck A, Bodai L, McDowell A, Seltmann H, Patrick S, Zouboulis CC and Kemény L: Propionibacterium acnes and lipopolysaccharide induce the expression of antimicrobial peptides and proinflammatory cytokines/chemokines in human sebocytes. Microbes Infect 8 2195-2205, 2006

54. Lee DY, Yamasaki K, Rudsil J, Zouboulis CC, Park GT, Yang JM and Gallo RL: Sebocytes express functional cathelicidin antimicrobial peptides and can act to kill propionibacterium acnes. J Invest Dermatol 128: 1863-1866, 2008.

55. Marples RR, Downing DT and Kligman AM: Control of free fatty acids in human surface lipids by Corynebacterium acnes. J Invest Dermatol 56: 127-131, 1971.

56. Götz F, Verheij HM and Rosenstein R: Staphylococcal lipases: Molecular characterisation, secretion, and processing. Chem Phys Lipids 93: 15-25, 1998.

57. Bastos MC, Ceotto H, Coelho ML and Nascimento JS: Staphylococcal antimicrobial peptides: Relevant properties and potential biotechnological applications. Curr Pharm Biotechnol 10: 38-61, 2009 .

58. Cogen AL, Yamasaki K, Sanchez KM, Dorschner RA, Lai Y, MacLeod DT, Torpey JW, Otto M, Nizet V, Kim JE, et al: Selective antimicrobial action is provided by phenol-soluble modulins derived from Staphylococcus epidermidis, a normal resident of the skin. J Invest Dermatol 130: 192-200, 2010.

59. Wang R, Braughton KR, Kretschmer D, Bach TH, Queck SY, Li M, Kennedy AD, Dorward DW, Klebanoff SJ, Peschel A, et al: Identification of novel cytolytic peptides as key virulence determinants for community-associated MRSA. Nat Med 13: 1510-1514, 2007.

60. Cogen AL, YamasakiK, Muto J, Sanchez KM, Crotty Alexander L, Tanios J, Lai Y, Kim JE, Nizet V and Gallo RL: Staphylococcus epidermidis antimicrobial delta-toxin (phenol-soluble modulin-gamma) cooperates with host antimicrobial peptides to kill group A Streptococcus. PLoS One 5: e8557, 2010.

61. McFall-Ngai M: Adaptive immunity: Care for the community. Nature 445: 153, 2007.

62. Cunnington AJ, Sim K, Deierl A, Kroll JS, Brannigan E and Darby J: 'Vaginal seeding' of infants born by caesarean section. BMJ 352: i227, 2016

63. Clemente JC and Dominguez-Bello MG: Safety of vaginal microbial transfer in infants delivered by caesarean, and expected health outcomes. BMJ 352: i1707, 2016

64. Matijašić M, Meštrović T, Perić M, Čipčić Paljetak H, Panek M, Vranešić Bender D, Ljubas Kelečić D, Krznarić Ž and Verbanac D: Modulating composition and metabolic activity of the gut microbiota in IBD patients. Int J Mol Sci 17: E578, 2016.

65. Sekirov I, Russell SL, Antunes LC and Finlay BB: Gut microbiota in health and disease. Physiol Rev 90: 859-904, 2010.

66. DeGruttola AK, Low D, Mizoguchi A and Mizoguchi E: Current understanding of dysbiosis in disease in human and animal models. Inflamm Bowel Dis 22: 1137-1150, 2016.

67. Cammarota G, Ianiro G, Bibbò S and Gasbarrini A: Fecal microbiota transplantation: A new old kid on the block for the management of gut microbiota-related disease. J Clin Gastroenterol 48 (Suppl 1): S80-S84, 2014

68. Patelarou E, Girvalaki C, Brokalaki H, Patelarou A, Androulaki Z and Vardavas C: Current evidence on the associations of breastfeeding, infant formula, and cow's milk introduction with type 1 diabetes mellitus: A systematic review. Nutr Rev 70: 509-519, 2012. 
69. Spagnuolo I, Patti A, Sebastiani G, Nigi L and Dotta F: The case for virus-induced type 1 diabetes. Curr Opin Endocrinol Diabetes Obes 20: 292-298, 2013.

70. Abela AG and Fava S: Association of incidence of type 1 diabetes with mortality from infectious disease and with antibiotic susceptibility at a country level. Acta Diabetol 50: 859-865, 2013

71. Muirhead CR, Cheetham TD, Court S, Begon M and McNally RJQ: How do childhood diagnoses of type 1 diabetes cluster in time? PLoS One 8: e60489, 2013.

72. Brugman S, Klatter FA, Visser JT, Wildeboer-Veloo AC, Harmsen HJ, Rozing J and Bos NA: Antibiotic treatment partially protects against type 1 diabetes in the Bio-Breeding diabetes-prone rat. Is the gut flora involved in the development of type 1 diabetes? Diabetologia 49: 2105-2108, 2006.

73. Mejía-León ME, Petrosino JF, Ajami NJ, Domínguez-Bello MG and de la Barca AM: Fecal microbiota imbalance in Mexican children with type 1 diabetes. Sci Rep 4: 3814, 2014

74. Vaarala O: Is the origin of type 1 diabetes in the gut? Immunol Cell Biol 90: 271-276, 2012.

75. Oliver-Krasinski JM and Stoffers DA: On the origin of the beta cell. Genes Dev 22: 1998-2021, 2008.

76. Giongo A, Gano KA, Crabb DB, Mukherjee N, Novelo LL, Casella G, Drew JC, Ilonen J, Knip M, Hyöty H, et al: Toward defining the autoimmune microbiome for type 1 diabetes. ISME J 5: 82-91, 2011.

77. Turnbaugh PJ, Bäckhed F, Fulton L and Gordon JI: Diet-induced obesity is linked to marked but reversible alterations in the mouse distal gut microbiome. Cell Host Microbe 3: 213-223, 2008.

78. Aron-Wisnewsky J and Clément K: The gut microbiome, diet, and links to cardiometabolic and chronic disorders. Nat Rev Nephrol 12: 169-181, 2016.

79. Cotillard A, Kennedy SP, Kong LC, Prifti E, Pons N, Le Chatelier E, Almeida M, Quinquis B, Levenez F, Galleron N, et al; ANR MicroObes consortium: Dietary intervention impact on gut microbial gene richness. Nature 500: 585-588, 2013.

80. Collins SM, Surette M and Bercik P: The interplay between the intestinal microbiota and the brain. Nat Rev Microbiol 10 735-742, 2012.

81. Anglin R, Surette M, Moayyedi P and Bercik P: Lost in translation: The gut microbiota in psychiatric illness. Can J Psychiatry 60: 460-463, 2015.

82. Mayer EA: Gut feelings: The emerging biology of gut-brain communication. Nat Rev Neurosci 12: 453-466, 2011.

83. Cryan JF and Dinan TG: Mind-altering microorganisms: The impact of the gut microbiota on brain and behaviour. Nat Rev Neurosci 13: 701-712, 2012.

84. Belizário JE and Napolitano M: Human microbiomes and their roles in dysbiosis, common diseases, and novel therapeutic approaches. Front Microbiol 6: 1050, 2015.

85. Guaní-Guerra E, Santos-Mendoza T, Lugo-Reyes SO and Terán LM: Antimicrobial peptides: General overview and clinical implications in human health and disease. Clin Immunol 135 : $1-11,2010$

86. Ong PY, Ohtake T, Brandt C, Strickland I, Boguniewicz M, Ganz T, Gallo RL and Leung DY: Endogenous antimicrobial peptides and skin infections in atopic dermatitis. $\mathrm{N}$ Engl J Med 347: 1151-1160, 2002.

87. Nomura I, Goleva E, Howell MD, Hamid QA, Ong PY, Hall CF, Darst MA, Gao B, Boguniewicz M, Travers JB, et al: Cytokine milieu of atopic dermatitis, as compared to psoriasis, skin prevents induction of innate immune response genes. J Immunol 171: 3262-3269, 2003.

88. Hooper LV, Littman DR and Macpherson AJ: Interactions between the microbiota and the immune system. Science 336 : 1268-1273, 2012.

89. Naik S, Bouladoux N, Wilhelm C, Molloy MJ, Salcedo R, Kastenmuller W, Deming C, Quinones M, Koo L, Conlan S, et al: Compartmentalized control of skin immunity by resident commensals. Science 337: 1115-1119, 2012

90. Trivedi B: Microbiome: The surface brigade. Nature 492: S60-S61, 2012.

91. Simpson DM and Ross R: The neutrophilic leukocyte in wound repair a study with antineutrophil serum. J Clin Invest 51: 2009-2023, 1972.

92. Mast BA and Schultz GS: Interactions of cytokines, growth factors, and proteases in acute and chronic wounds. Wound Repair Regen 4: 411-420, 1996.
93. Werner $\mathrm{S}$ and Grose R: Regulation of wound healing by growth factors and cytokines. Physiol Rev 83: 835-870, 2003.

94. Kostarnoy AV, Gancheva PG, Logunov DY, Verkhovskaya LV, Bobrov MA, Scheblyakov DV, Tukhvatulin AI, Filippova NE, Naroditsky BS and Gintsburg AL: Topical bacterial lipopolysaccharide application affects inflammatory response and promotes wound healing. J Interferon Cytokine Res 33: 514-522, 2013.

95. Kanno E, Kawakami K, Ritsu M, Ishii K, Tanno H, Toriyabe S, Imai Y, Maruyama R and Tachi M: Wound healing in skin promoted by inoculation with Pseudomonas aeruginosa PAO1: The critical role of tumor necrosis factor- $\alpha$ secreted from infiltrating neutrophils. Wound Repair Regen 19: 608-621, 2011.

96. Ferreira MO, Costa PC and Bahia MF: Effect of São Pedro do Sul thermal water on skin irritation. Int J Cosmet Sci 32: 205-210, 2010

97. Goldman MP, Merial-Kieny C, Nocera $T$ and Mery S: Comparative benefit of two thermal spring waters after photodynamic therapy procedure. J Cosmet Dermatol 6: 31-35, 2007.

98. Barolet D, Lussier I, Mery S and Merial-Kieny C: Beneficial effects of spraying low mineral content thermal spring water after fractional photothermolysis in patients with dermal melasma. J Cosmet Dermatol 8: 114-118, 2009

99. Faga A, Nicoletti G, Gregotti C, Finotti V, Nitto A and Gioglio L: Effects of thermal water on skin regeneration. Int J Mol Med 29: 732-740, 2012

100. Nicoletti G, Corbella M, Jaber O, Marone P, Scevola D and Faga A: Non-pathogenic microflora of a spring water with regenerative properties. Biomed Rep 3: 758-762, 2015.

101. Aries MF, Fabre P, Duplan H, Hernandez Pigeon H, Galliano MF, Castex Rizzi N, Bessou Touya $S$ and Nguyen T: I-modulia, an Aquaphilus dolomiae extract, stimulates innate immune response through Toll like receptor activation. J Am Acad Dermatol 70 (Suppl 1): AB63, 2014.

102. Mahé YF, Martin R, Aubert L, Billoni N, Collin C, Pruche F, Bastien P, Drost SS, Lane AT and Meybeck A: Induction of the skin endogenous protective mitochondrial MnSOD by Vitreoscilla filiformis extract. Int J Cosmet Sci 28: 277-287, 2006.

103. Mahé YF, Perez MJ, Tacheau C, Fanchon C, Martin R, Rousset F and Seite S: A new Vitreoscilla filiformis extract grown on spa water-enriched medium activates endogenous cutaneous antioxidant and antimicrobial defenses through a potential Toll-like receptor 2/protein kinase $\mathrm{C}$, zeta transduction pathway. Clin Cosmet Investig Dermatol 6: 191-196, 2013.

104. Castex-Rizzi N, Charveron M and Merial-Kieny C: Inhibition of TNF-alpha induced-adhesion molecules by Avène Thermal Spring Water in human endothelial cells. J Eur Acad Dermatol Venereol 25 (Suppl 1): 6-11, 2011

105. Ghersetich I and Lotti TM: Immunologic aspects: Immunology of mineral water spas. Clin Dermatol 14: 563-566, 1996.

106. Leavis HL, Bonten MJ and Willems RJ: Identification of high-risk enterococcal clonal complexes: Global dispersion and antibiotic resistance. Curr Opin Microbiol 9: 454-460, 2006.

107. Miragaia M, Thomas JC, Couto I, Enright MC and de Lencastre H: Inferring a population structure for Staphylococcus epidermidis from multilocus sequence typing data. J Bacteriol 189: 2540-2552, 2007

108. Robinson DA and Enright MC: Multilocus sequence typing and the evolution of methicillin-resistant Staphylococcus aureus. Clin Microbiol Infect 10: 92-97, 2004.

109. Robinson DA, Sutcliffe JA, Tewodros W, Manoharan A and Bessen DE: Evolution and global dissemination of macrolide-resistant group A streptococci. Antimicrob Agents Chemother 50: 2903-2911, 2006.

110. Löfmark S, Jernberg C, Jansson JK and Edlund C Clindamycin-induced enrichment and long-term persistence of resistant Bacteroides spp. and resistance genes. J Antimicrob Chemother 58: 1160-1167, 2006.

111. Sjölund M, Tano E, Blaser MJ, Andersson DI and Engstrand L: Persistence of resistant Staphylococcus epidermidis after single course of clarithromycin. Emerg Infect Dis 11: 1389-1393, 2005. 